(3)

Volume 20, 2017

\title{
The INFORMINg NEEDS OF Procurement OfFICERS IN ISRAEL
}

$\begin{array}{lll}\text { Dan Bouhnik } & \begin{array}{l}\text { Jerusalem College of Technology, } \\ \text { Jerusalem, Israel }\end{array} & \text { bouhnik@jct.ac.il } \\ \text { Yahel Giat* } & \begin{array}{l}\text { Jerusalem College of Technology, } \\ \text { Jerusalem, Israel }\end{array} & \text { yahel@jct.ac.il } \\ \text { Issachar Zarruk } & \begin{array}{l}\text { Bar-Ilan University, Ramat-Gan, } \\ \text { Israel }\end{array} & \text { Issachar.zarruk@biu.ac.il } \\ * \text { Corresponding author } & \end{array}$

\section{ABSTRACT}

Aim/Purpose

Background

Methodology

Contribution

Findings

Recommendations for Practitioners

Recommendation for Researchers

Impact on Society
To develop and introduce a questionnaire that investigates the informing needs, information-seeking behavior, and supplier selection of procurement officers in Israel. The questionnaire's internal consistency reliability is given. Additionally, we describe the demographic description of the procurement officers in Israel.

Procurement science is an important field that affects firms' profits in the private sector and is significant to growth, innovation, sustainability, and welfare in the public sector. There is little research about the informing needs of procurement officers in general and particularly in Israel.

A quantitative questionnaire that is sent to all the procurement officers in Israel's purchasing and logistics managers association.

The questionnaire that is developed in this paper may be used by other researchers and practitioners to evaluate the informing needs of procurement officers.

The typical procurement officer is male, with a bachelor degree and is digitally proficient.

The procuring side can use the questionnaire to develop better tools for obtaining information efficiently. The supplying side can use this knowledge to improve its exposure to potential customers and address its customer's needs better.

The questionnaire can address theoretical questions such as how digital literacy affects the procurement process and provide empirical findings about active research areas such as supplier selection and information-seeking behavior.

Improvement in the informing-related issues of the procurement process has the potential to reduce costs, drive growth, and discourage corruption.

Accepting Editor Raafat Saadé | Received: February 16, 2017 | Revised: April 1, May 23, 2017 | Accepted: June 8, 2017.

Cite as: Bouhnik, D, Giat, Y., \& Zarruk, I. (2017). The informing needs of procurement officers in Israel. Informing Science: the International Journal of an Emerging Transdiscipline, 20, 149-165. Retrieved from http://www.informingscience.org/Publications/3765

(CC BY-NC 4.0) This article is licensed to you under a Creative Commons Attribution-NonCommercial 4.0 International License. When you copy and redistribute this paper in full or in part, you need to provide proper attribution to it to ensure that others can later locate this work (and to ensure that others do not accuse you of plagiarism). You may (and we encourage you to) adapt, remix, transform, and build upon the material for any non-commercial purposes. This license does not permit you to use this material for commercial purposes. 
Future Research Future research will examine the relationship between the various variables and demographic features to understand why specific informing needs and information-seeking behaviors arise.

Keywords procurement, informing needs, e-procurement, Israel

\section{INTRODUCTION}

The science of procurement is one of the most important fields of operation to both public and private organizations. For example, public procurement in the OECD countries is between 12 percent and 29 percent of government expenditures (OECD, 2017). Moreover, with the rapid progress of technological tools, procurement has been evolving rapidly and requires advanced sets of skills, and, as a result, the effect of procurement on the viability of the organization is ever more profound (Picoto, Bélanger, \& Palma-dos-Reis, 2014). The fact that state-of-the-art procurement tools require advanced technological sophistication affects the likelihood of their adoption. In addition, this implies that the use of these tools and the needs of the users of these tools depend on the organization's know-how and proficiency of such tools (Raymond, Croteau, \& Bergeron, 2012).

In this paper, we present a questionnaire that is used in a largescale research project about the informing needs and internet usage of procurement officers in Israel (Zarruk, 2016). There are approximately 1600 members in the Israeli Purchasing \& Logistics Managers Association in Israel. The questionnaire was sent to a random subset of four hundred procurement officers with 312 questionnaires completed, making it the most comprehensive research about the informing needs of procurement officers in Israel.

Procurement and the needs of the procurement officers are tied with the economy in which they operate. In addition, the country's digital infrastructure and the digital skills of the officers influence their informing needs and usage. Therefore, this research and its results must be understood in the context of Israel's economy and communications infrastructure. Culturally and economically speaking, Israel is considered a developed western country and a member of the OECD since 2010. According to the World Bank's data, in 2015, Israel's GDP was 300 billion current US dollars, and with a population of less than 8.4 million, its GDP per-capita in 2015 was 35,700 current US dollars, placing it within the top 30 countries of the world (World Bank, 2017). Technologically speaking, Israel is very advanced. The CIA World Factbook assesses its telephone system as the "most highly developed in the Middle East". The domestic telephone system is a "good system of coaxial cable and microwave radio relay; all systems are digital; competition among both fixed-line and mobile cellular providers results in good coverage countrywide". The number of landlines and cellular lines per 100 inhabitants as of July 2015 was 131 and 42, respectively. The number of internet users as of July 2015 was estimated at $79 \%$, placing it $58^{\text {th }}$ in the world (CIA, 2017).

The questionnaire covers a number of fields that relate to a number of research questions as follows:

- What are the topics and issues that procurement officers search? What are the information channels that the officers use to search for information? How frequently do they use each of these information channels?

- What are the factors/reasons affecting their decisions to use the internet for supplier-related issues?

- What are the criteria that they use to evaluate and select suppliers? Are they able to obtain information about the suppliers on the internet?

- How do they use the internet to obtain information? Do they find it difficult to use the internet to obtain information? What languages do they use? Are they assisted by colleagues or friends? What technological tools, application and devices do they use?

- How do they assess the quality of the information obtained on the internet? What criteria do they use to assess the information's quality and accuracy? Are they satisfied with the quality/accuracy of the information obtained from the internet? 
- Is the information obtained from the internet about suppliers beneficial? How much information do they obtain from each channel of information and how useful it is?

In addition, using the demographic characteristics of the participants we will be able to answer questions such as:

- Is there a difference between the informing needs of procurement officers in the public sector and the private sector?

- How does the technological literacy and/or academic education of officers influence these informing needs?

Currently, there is no large-scale research about the informing needs of procurement officers in Isra$\mathrm{el}$, and, therefore, the immediate contribution of this paper and the follow-up research is to address the lacuna. The paper's contribution, however, goes beyond its geographic borders. The questionnaire allows for an analysis distinguishing between public and private procurement and how the officers' demographic features affect their needs. These results can teach us about informing needs in other countries and societies.

The answers to these questions are useful for all those who are related to the field of procurement. First, organizations who are in the buying side of the procurement process must understand the needs of their procurement departments so that they can facilitate their in-house procuring operations. Second, suppliers who understand the needs of their buyers should be wise enough to accommodate those needs in order to improve their exposure to potential buyers and to meet their criteria. Third, policy makers should have a better understanding of how the many aspects of informing affect the procurement process, as this is one of the major drives of growth, innovation, welfare and (unfortunately) corruption in the economy.

The questionnaire is an informing system whose main clients are the procurement officers (see Gill and Bhattacherjee, 2007). Following Gill's (2008) structural complexity framework, one may use this questionnaire to investigate whether it's structural complexity decreases with the procurement officers' level of expertise (i.e., their tenure) and whether this also affects their informing needs.

\section{LITERATURE REVIEW}

Procurement has been investigated in many contexts by researchers. In the following review, we focus our attention to the area of e-procurement, which is now the most common ways procurement is conducted in medium and large enterprises.

In its most simple definition, e-procurement is any technology solution that facilitates private and public procurement using the internet (Presutti, 2003). Effective implementation of e-procurement creates added value to the supply chain and improves its performance (Persutti, 2003; Puschmann \& Alt, 2005). Reviews of this field are in Schoenherr and Tummala (2007) and Maloni, Hiatt, and Astrachan (2017).

Many empirical papers about e-procurement focus on a single country (e.g., Auriol, Straub, \& Flochel, 2016; Costa, Arantes, \& Taveres, 2013; Svidronova \& Mikus, 2015; Uyarra, Edler, Gee, Georghiou, \& Yeow, 2014) or a relatively homogenous region (e.g., Amann, Roehrich, Eßig, \& Harland, 2014; Bof \& Casella, 2015; Harper, Ramirez, \& Ayala, 2016). This relative homogeneity is important since the informing needs of procurement officers from societies with different levels of digital literacy will be starkly different (Huang, Tran, Nguyen, \& Nazir, 2016). We may use our research to examine this by comparing the informing needs of officers with different levels of academic background. Another approach to examine this is to see if and how informing needs change with the officers' age. There is empirical evidence that age is negatively correlated with digital literacy (Eshet-Alkalai \& Amichai-Hamburger, 2004; Eshet-Alkalai \& Chajut, 2009). Thus, different age groups can indicate whether digital literacy affects the informing needs. 
Many of the aforementioned papers discuss procurement in the public sector, namely, public procurement. This definition includes state and local governmental offices and agencies as well as public funded nonprofits such as public universities and colleges. Public procurement is a significant economic factor, which, for example, accounted to $10 \%$ of the GDP in the USA and $16 \%$ of the GDP in the European Union (Cernat \& Kutlina-Dimitrova, 2015). Researchers describe many roles of public procurement. These include the role of inducing innovation, development and economic growth (e.g., Edler \& Georghiou, 2007; Preuss, 2007; Uyarra et al., 2014), achieving environmental goals (e.g., Amann et al., 2014; Bof \& Casella, 2015), and the reduction of public corruption (e.g., Neupane, Soar, \& Vaidya, 2014).

It follows, therefore, that while private procurement focuses on the added-value to the supply chain (e.g., Puschmann \& Alt, 2005), public procurements roles support non-monetary goals along with monetary goals. Public procurement also differs from private procurement in that the former is bound to many regulations and screening. The constant public demand to control spending and fight corruption results in rigid rules that the procurement officers must follow. Moreover, as can be learnt from Balaeva and Yakovlev (2015), these strict regulations also translate to significant costs.

In certain countries, all public procurement is done under the exact same rules and regulations. See, for example, Páez (2010), who describes public procurement in Ecuador and its effect on the private procurement. In Israel, however, there is a difference, between government procurement and other public procurement. Government offices in the state level are bound to the same processes and controls, whereas local authorities, public nonprofit, and other public institutions may have different procuring systems and processes.

The main objective of this research is to gauge the informing needs of procurement officers. One of the first papers to discuss informing issues of procurement officers is Sheth (1973) who develops a model for industrial buyer behavior. Sheth refers to these officers as "purchasing agents" and claims that they are exposed to vast and disproportional amounts of trade information sources.

Busse, Meinlschmidt, and Foerstl (2016) investigate the informing needs of supply chain managers focusing on procurement and sustainability. Similarly, Bouhnik, Giat, and Zarook (2016) describe the information-seeking behavior of university procurement officers in Israel. Their participants belong to public entities whose behavior may differ from procurement officers of private corporations.

Spekman (1988) identifies four categories of information sources: personal and commercial; personal and noncommercial; commercial but non-personal; non-personal and noncommercial. In the past two decades these information sources are mostly internet-based (e.g., Muffatto \& Payaro, 2004). These information sources may be categorized as formal or informal. Formal sources are investigated in Bouhnik and Giat (2015) and informal sources are the focus of Jaakkola, Aarikka-Stenroos, and Kimmel (2014). Indeed, Sanderson, Lonsdale, Mannion, and Matharu (2015) claim that both types of sources are needed, especially in risky environments. Following this area of research we examine the use of formal, informal, and external (i.e., out of state) sources by procurement officers.

Anderson, Chu, and Weitz (1987) describe different levels of informing needs for different stages of the procurement officers. When procuring a new product the need for information is highest, followed by a modified rebuy situation, and a minimal level of information is needed for a straight rebuy situation. Other researchers investigate the different characteristics and informing needs of procurement officers in different industries or companies (e.g., Muffatto \& Payaro, 2004). In this research, however, we do not distinguish between the procurement stage or the industry in which the procurement officers are operating.

Supplier selection is one of the most investigated areas in the field of procurement. This field dates back to Dickson (1966) who finds 23 criteria by which procurement officers assess and select suppliers. Dickson reports that the four top-ranking criteria are 'quality', 'delivery', 'performance-history' and 'warranty \& claims policies'. Sheth (1973) finds that 'satisfaction from previous purchases is also 
highly important to procurement officers. Weber, Current, and Benton (1991) report a rise in the importance of 'repair services and geographic locations'. Recently, Bouhnik et al. (2016) find that the five most important criteria for public procurement officers are 'quality', 'price', 'performance history', 'delivery' and 'technical ability'.

There are scores of supplier selection models, such as elimination models (e.g., Crow, Olshavsky, \& Summers, 1980), analytic hierarchy process models (e.g., Atkinson, Bayazit, \& Karpak, 2015; Saaty, 1980), and data envelopment analysis models (e.g., Saen \& Gershon, 2010). The common feature of all these models is that it is initially required to understand the relative importance of the different criteria for supplier assessment. We therefore devote a number of questions to the understanding the criteria used by the procurement officers and their informing needs and information seeking behavior with respect to supplier selection and assessment.

\section{RESEARCH PARTICIPANTS}

This research is based on Zarruk (2016). The participants of this study are procurement officers in Israel. There are approximately 1600 members of the Israeli Purchasing \& Logistics Managers Association. A questionnaire was sent to a random sample of 400 procurement officers. 312 of the 400 $(78 \%)$ completed all the questionnaires, and they comprise the participants of this study. Membership in the association requires providing the workplace's confirmation that the applicant is actively involved in procurement, and, therefore, we assume that all those who responded to the questionnaire are engaged in procurement. The participants' demographic characteristics are given in Tables 1 and 2. Table 1 contains textual variables: gender; language, level of education, sector, procurement activity, and procurement budget. Table 2 contains the numerical demographic variables.

Table 1. Demographics of the study's participants - textual variables

\begin{tabular}{|c|c|c|c|c|c|c|c|c|}
\hline Item & Value & $\mathrm{N}(\%)$ & Item & Value & $\mathrm{N}(\%)$ & Item & Value & $\mathrm{N}(\%)$ \\
\hline \multirow{2}{*}{ 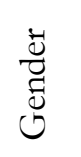 } & Men & $268(86 \%)$ & \multirow{4}{*}{ 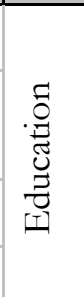 } & High school & $34(11 \%)$ & \multirow{3}{*}{ 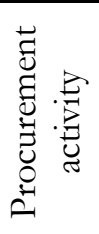 } & Local & $223(72 \%)$ \\
\hline & Women & $44(14 \%)$ & & $\begin{array}{l}\text { Professional } \\
\text { certificate }\end{array}$ & $20(6 \%)$ & & Overseas & $14(5 \%)$ \\
\hline \multirow{6}{*}{ 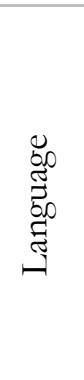 } & Hebrew & $246(79 \%)$ & & B.A. & $212(68 \%)$ & & Local \& overseas & $75(24 \%)$ \\
\hline & English & $49(16 \%)$ & & M.A. or higher & $46(15 \%)$ & \multirow{5}{*}{ 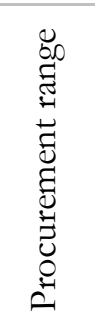 } & $<0.5$ mil. ILS & $53(17 \%)$ \\
\hline & Russian & $1(0 \%)$ & \multirow{3}{*}{$\begin{array}{l}0 \\
\stackrel{0}{0} \\
\mathscr{U}\end{array}$} & Private & $270(87 \%)$ & & $0.5-1$ mil. ILS & $33(11 \%)$ \\
\hline & French & $12(4 \%)$ & & Public & $35(11 \%)$ & & $1-5$ mil. ILS & $109(35 \%)$ \\
\hline & Arabic & $1(0 \%)$ & & Government & $7(2 \%)$ & & $5-10$ mil. ILS & $60(19 \%)$ \\
\hline & Spanish & $3(1 \%)$ & & & & & $>10$ mil. ILS & $57(18 \%)$ \\
\hline
\end{tabular}

Table 2. Demographics of the study's participants - numerical variables

\begin{tabular}{|l|c|c|c|}
\hline Characteristics & M & SD & Range \\
\hline Age & 45.34 & 11.36 & $26-65$ \\
\hline Years of schooling & 15.15 & 1.46 & $12-19$ \\
\hline Seniority & 9.20 & 18.19 & $3-35$ \\
\hline Knowledge of computer applications & 4.08 & 0.91 & $3-5$ \\
\hline Knowledge of new technologies & 4.03 & 0.92 & $3-5$ \\
\hline
\end{tabular}




\section{QUESTIONNAIRE'S COMPONENTS AND INTERNAL CONSISTENCY RELIABILITY}

The questionnaire comprises seven parts and is provided in the Appendix. Questions 1-11 examine the demographic and socio-economic characteristics of the participants. Questions 12-14 ask about the informing needs and channels of information. Questions 15-16 ask about the cause for seeking information about suppliers. Questions 17-18 ask about the criteria for supplier assessment. Questions 19-27 ask about how they seek information about suppliers. Questions 28-30 ask about the quality/accuracy of the information about suppliers. Questions 31-34 focus on whether the information about suppliers is beneficial.

The questionnaire underwent a pre-test among 40 procurement officers to determine its internal consistency reliability. These 40 officers are not participants of the study. The internal consistency reliability is measured using Cronbach's alpha, which is the most common measure for reliability (Tavakol \& Dennick, 2011). The Cronbach's alpha of the variables range between medium to very high $(0.6-0.99)$. The questionnaire was sent to participants using Google Docs and the participants were asked to complete it on-line. In what follows, we detail variables that comprise multiple items within questions in the questionnaire.

Question 14 asks about the frequency of use of the information channels. The question comprises 24 items that are grouped into three variables of information channels.

- Official channels of information - 9 items including professional unions, publications and professional journals, etc.

- Incidental channels of information - 11 items including the internet, datamining companies, professional exhibits and fairs, etc.

- External channels of information - 4 statements including trade publications, foreign attachés, overseas delegations, etc.

The distinction between formal and informal (i.e., incidental) sources has been suggested by Sanderson et al. (2015). In Table 3, we describe the mean and standard deviation of these channels of information and report these variables' internal consistency reliability (Cronbach's alpha).

Table 3. Channels of Information

\begin{tabular}{|l|c|c|c|c|c|}
\hline Variables & Items & M & SD & Range & Alpha \\
\hline Official channels & $1-9$ & 2.85 & 0.80 & $2.00-4.22$ & .78 \\
\hline Incidental channels & $10-20$ & 3.56 & 0.29 & $3.08-4.17$ & .74 \\
\hline External channels & $21-24$ & 2.04 & 1.19 & $1.00-3.67$ & .67 \\
\hline All channels & $1-24$ & 2.82 & 0.67 & $2.01-3.96$ & .83 \\
\hline
\end{tabular}

Question 16 asks about the reasons for seeking information about suppliers on the internet and comprises 20 items. These items, as well as the items in the other questions, underwent a construct validation process with a panel of practicing procurement officers. After the validation process the items of Question 16 were grouped into five variables as follows.

- Convenience/saving time - comprises items 1, 3,13 and 14, whose common factor is easier access to information regarding supplier, such as accessibility, saving time, etc.

- Financial - comprises items 2,11,12 and 19 whose common feature is the financial aspect of the search or financial savings, such as inexpensive, organizations' internet awareness, etc.

- Need for more information - comprises items 4, 6, 7, 8, 9, 15, 16 and 17. For example, dissatisfaction with the information found through other channels, ability to learn about various supplier features, etc. 
- Second opinion - this variable comprises items 10,18 and 20. These are intuition, help from others, and generally updated.

- Anonymity -This variable is item 5.

In Table 4, we describe the mean and standard deviation of these variables and report these variables' internal consistency (Cronbach's alpha).

Table 4. Variables for reasons of search for information about suppliers on the internet

\begin{tabular}{|l|c|c|c|c|c|}
\hline Variable & Items & M & SD & Range & Alpha \\
\hline Convenience & $1,3,13,14$ & 2.94 & 1.22 & $1.00-4.50$ & .96 \\
\hline Financial & $2,11,12,19$ & 3.19 & 1.34 & $1.00-5.00$ & .95 \\
\hline Need for more information & $4,6,7,8,9,15,16,17$ & 2.80 & 1.17 & $1.00-4.25$ & .97 \\
\hline Second opinion & $10,18,20$ & 2.75 & 1.26 & $1.00-4.00$ & .96 \\
\hline All Items & $1-20$ & 2.90 & 1.23 & $1.00-4.33$ & .99 \\
\hline
\end{tabular}

Questions 17 and 18 each comprise 23 items originally suggested by Dickson (1966). These questions examine the criteria for supplier selection and whether information is found on the internet about each of the criteria. The internal consistency of questions 17 and 18 is high; alpha $=0.86$ and 0.98 , respectively.

Question 24 comprises five items about whether the participant asks for assistance in the process of searching for supplier information on the internet. After the validation process these were grouped into two variables as follows.

- Self-search - the items that indicate the participant does not require help.

- Help - the items that indicate the participant asks for assistance.

In Table 5, we describe the mean and standard deviation of these variables and report these variables' internal consistency (Cronbach's alpha).

Table 5. Variables about the manner in which the search is conducted

\begin{tabular}{|l|c|c|c|c|c|}
\hline Variable & Items & $\mathrm{M}$ & $\mathrm{SD}$ & Range & Alpha \\
\hline Self-search & $1-2$ & 3.79 & 1.60 & $1.50-5.00$ & .98 \\
\hline Request for help & $3-5$ & 3.23 & 1.50 & $1.00-5.00$ & .96 \\
\hline All items & $1-5$ & 3.45 & 1.50 & $1.20-5.00$ & .97 \\
\hline
\end{tabular}

Question 28 comprises nine items about how the participant determines the quality/accuracy of the information on the internet. After the validation process these were grouped into three variables: formal data (5 items), site friendliness (3 items) and information security (1 item). In Table 6 , we describe the mean and standard deviation of these variables and report their internal consistency (Cronbach's alpha).

Table 6. Variables about assessing information quality

\begin{tabular}{|l|c|c|c|c|c|}
\hline Variable & Items & $\mathrm{M}$ & $\mathrm{SD}$ & Range & Alpha \\
\hline Friendliness & $1-5$ & 2.84 & 1.45 & $1.00-4.40$ & .93 \\
\hline Formal details & $6-8$ & 2.57 & 1.17 & $1.00-4.00$ & .77 \\
\hline All items & $1-9$ & 2.72 & 1.32 & $1.00-4.22$ & .95 \\
\hline
\end{tabular}


Question 31 examines from which channels of information the participant receives most of the information. This question differs from Question 14, which examines the extent of use of the channels of information. The items construct the same variables described above in Table 3. In Table 7, we describe the mean and standard deviation of these variables and report their internal consistency (Cronbach's alpha).

Table 7. Channels of Information

\begin{tabular}{|l|c|c|c|c|c|}
\hline Variables & Items & $\mathrm{M}$ & $\mathrm{SD}$ & Range & Alpha \\
\hline Official channels & $1-9$ & 3.00 & 0.73 & $2.22-4.11$ & .77 \\
\hline Incidental channels & $10-20$ & 3.06 & 0.35 & $2.83-4.33$ & .72 \\
\hline External channels & $21-24$ & 1.78 & 0.83 & $1.00-3.00$ & .65 \\
\hline All channels & $1-24$ & 3.15 & 0.51 & $2.46-3.88$ & .85 \\
\hline
\end{tabular}

\section{CONCLUSIONS}

In this paper we introduce a questionnaire used to determine the informing needs of procurement officers in Israel. The questionnaire is designed to cover various aspects of the information-seeking behavior of these officers about suppliers. The multiple-item questions of the questionnaire were validated using a panel of experts. The internal consistency reliability (Cronbach's alpha) of the questionnaire's questions ranges between 0.65 (medium) to 0.99 (very high). In addition, we describe the demographic features of the procurement officers in Israel. The procurement officers are mostly male; the majority has at least a bachelor's degree and is digitally proficient.

An overwhelming majority of the participants work in the private sector. This suggests that the private sector itself may be broken into different industry sectors to test for differences across sectors. In addition, an updated version of this questionnaire is to include distinction between different types of procurement, from new-product buying to straight rebuy situations (recall Anderson et al., 1987). To ensure that each subgroup has sufficiently many participants increasing the sample group may be needed.

Future research using this questionnaire will examine the actual informing needs of the officers and their information-seeking behavior. Moreover, by examining the relationship between the various variables and demographic features we will be able to understand why specific informing needs and information-seeking behaviors arise. This will facilitate the development of tools addressing those needs.

\section{REFERENCES}

Amann, M., K. Roehrich, J., Eßig, M., \& Harland, C. (2014). Driving sustainable supply chain management in the public sector: The importance of public procurement in the European Union. Supply Chain Management: An International Journal, 19(3), 351-366.

Anderson, E., Chu, W., \& Weitz, B. (1987). Industrial purchasing: An empirical exploration of the buyclass framework. The Journal of Marketing, 51(July), 71-86.

Auriol, E., Straub, S., \& Flochel, T. (2016). Public procurement and rent-seeking: The case of Paraguay. World Development, 77, 395-407.

Atkinson, M. A., Bayazit, O., \& Karpak, B. (2015). A case study using the analytic hierarchy process for IT outsourcing decision making. International Journal of Information Systems and Supply Chain Management (IJISSCM), $8(1), 60-84$. 
Balaeva, O., \& Yakovlev, A. A. (2015). Estimation of costs in the Russian public procurement system: A case study of Voronezh State University. Higher School of Economics Research Paper No. WP BRP 41.

Bof, F., \& Casella, G. (2015). Public e-procurement as a key-impact factor in the UE welfare context-The Italian public e-markets: Research findings and E-solutions analysis. In Information and Communication Technology, Electronics and Microelectronics (MIPRO), 2015 38th International Convention on (pp. 1434-1443). IEEE.

Bouhnik, D., \& Giat, Y. (2015). ISO 9001 as a tool for improving knowledge management in business ecosystems. International Journal of Knowledge-Based Development, 6(3), 261-272.

Bouhnik, D., Giat, Y., \& Zarruk, I. (2016). University procurement officers' use of technology when seeking information. Issues in Informing Science and Information Technology, 13, 195-208. Retrieved from http://www.informingscience.org/Publications/3473

Busse, C., Meinlschmidt, J., \& Foerstl, K. (2016). Managing information processing needs in global supply chains: A prerequisite to sustainable supply chain management. Journal of Supply Chain Management. 53(1), 87-113.

Cernat, L., \& Kutlina-Dimitrova, Z. (2015). International public procurement: From scant facts to hard data. Retrieved March 10, 2017 from http://trade.ec.europa.eu/doclib/docs/2015/april/tradoc 153347.pdf

CIA. (2017). The world factbook - Israel. Retrieved March 10, 2017 from https://www.cia.gov/library/publications/the-world-factbook/geos/is.html

Costa, A. A., Arantes, A., \& Tavares, L. V. (2013). Evidence of the impacts of public e-procurement: The Portuguese experience. Journal of Purchasing and Supply Management, 19(4), 238-246.

Crow, L., Olshavsky, R., \& Summers, J. (1980). Industrial buyers' choice strategies: A protocol analysis. Journal of Marketing Research, 17(1), 34-44.

Dickson, W. (1966). An analysis of vendor selection systems and decisions. Journal of Purchasing, 2(1), 5-17.

Edler, J., \& Georghiou, L. (2007). Public procurement and innovation - Resurrecting the demand side. Research Policy, 36(7), 949-963.

Eshet-Alkali, Y., \& Amichai-Hamburger, Y. (2004). Experiments in digital literacy. CyberPsychology \& Behavior, 7(4), 421-429.

Eshet-Alkalai, Y., \& Chajut, E. (2009). Changes over time in digital literacy. CyberPsychology \& Behavior, 12(6), 713-715.

Gill, G. (2008). Structural complexity and effective informing. Informing Science: the International Journal of an Emerging Transdiscipline, 11, 253-279. Retrieved from https://www.informingscience.org/Publications/448

Gill, G., \& Bhattacherjee, A. (2007). The informing sciences at a crossroads: The role of the client. Informing Science Journal, 10, 17-39. Retrieved from https://www.informingscience.org/Publications/454

Harper, L. E., Ramirez, A. C. C., \& Ayala, J. E. M. (2016). Elements of public procurement reform and their effect on the public sector in LAC. Journal of Public Procurement, 16(3), 347-373.

Huang, D. C., Tran, Q. D., Nguyen, T. Q. T., \& Nazir, S. (2016). Initial adoption vs. institutionalization of eprocurement in construction firms: The role of government in developing countries. In M. Khosrow-Pour (Ed.), International Business: Concepts, Methodologies, Tools, and Applications (Vol 2.), (pp. 1275-1295). IGI Global.

Jaakkola, E., Aarikka-Stenroos, L., \& Kimmel, A. (2014). Leveraging customer experience communication. In J. Kandampully (Ed.), Customer experience management: enhancing experience and value through service management (pp. 45-72). Dubuque, Iowa: Kendall Hunt.

Maloni, M. J., Hiatt, M. S., \& Astrachan, J. H. (2017). Supply management and family business: A review and call for research. Journal of Purchasing and Supply Management, 23(2), 123-136. doi: 10.1016/j.pursup.2016.12.002

Muffatto, M., \& Payaro, A. (2004). Integration of web-based procurement and fulfillment: A comparison of case studies. International Journal of Information Management, 24, 295-311. 
Neupane, A., Soar, J., \& Vaidya, K. (2014). An empirical evaluation of the potential of public e-procurement to reduce corruption. Australasian Journal of Information Systems, 18(2), 21-44.

OECD. (2017). Public procurement. Retrieved February 15, 2017 from http://www.oecd.org/gov/ethics/publicprocurement.htm

Páez, F. (2010) Implementation official public procurement system of Ecuador. In Proceedings of the $5^{\text {th }}$ international public procurement conference (chapter VII, paper 11), IPPC. Retrieved March 5, 2017 from http://www.ippa.org/IPPC5/Proceedings/Part7/PAPER7-11.pdf

Picoto, W. N., Bélanger, F., \& Palma-dos-Reis, A. (2014). An organizational perspective on m-business: Usage factors and value determination. European Journal of Information Systems, 23(5), 571-592.

Presutti, W. D. (2003). Supply management and e-procurement: creating value added in the supply chain. Industrial Marketing Management, 32(3), 219-226.

Preuss, L. (2007). Buying into our future: Sustainability initiatives in local government procurement. Business Strategy and the Environment, 16, 354-365.

Puschmann, T., \& Alt, R. (2005). Successful use of e-procurement in supply chains. Supply Chain Management: An International Journal, 10(2), 122-133.

Raymond, L., Croteau, A.-M., \& Bergeron, F. (2012). The strategic role of IT as an antecedent to the IT sophistication and IT performance of manufacturing SMEs. International Journal on Advances in Systems and Measurements, 4(3-4), 203-211.

Saaty, T. L. (1980). The analytic hierarchy process. New York: McGraw-Hill.

Saen, R., \& Gershon, M. (2010). Supplier selection by the pair of AR-NF-IDEA models. International Journal of Information Systems and Supply Chain Management (IJISSCM), 3(4), 25-41.

Sanderson, J., Lonsdale, C., Mannion, R., \& Matharu, T. (2015). Theories about procurement and supply chain management. In J. Sanderson, C. Lonsdale, R. Mannion, \& T. Matharu, Towards a framework for enhancing procurement and supply chain management practice in the NHS: lessons for managers and clinicians from a synthesis of the theoretical and empirical literature (Chapter 3). Southampton, UK: NIHR Journals Library.

Schoenherr, T., \& Tummala, V. R. (2007). Electronic procurement: A structured literature review and directions for future research. International Journal of Procurement Management, 1(1-2), 8-37.

Sheth, J. N. (1973). A model of industrial buyer behavior. Journal of Marketing, 37(4), 50-56.

Spekman, R. E. (1988). Strategic supplier selection: Understanding long-term buyer relationships. Business Horizons, 31(4), 75-81.

Svidronova, M. M., \& Mikus, T. (2015). E-procurement as the ICT innovation in the public services management: case of Slovakia. Journal of Public Procurement, 15(3), 317-340.

Tavakol, M., \& Dennick, R. (2011). Making sense of Cronbach's alpha. International Journal of Medical Education, 2, 53-55.

Uyarra, E., Edler, J., Gee, S., Georghiou, L., \& Yeow, J. (2014). UK: UK public procurement of innovation: The UK case. In V. Lember, R. Kattel, \& Kalvet T. (Eds.), Public procurement, innovation and policy: International perspectives (pp. 233-257). Berlin: Springer-Verlag.

Weber, C. A., Current, J. R., \& Benton, W. C. (1991). Vendor selection criteria and methods. European Journal of Operational Research, 50(1), 2-18.

World Bank (2017). Israel. Retrieved February 15, 2017 from http://data.worldbank.org/country/israel

Zarruk, I. (2016). Information seeking behavior patterns on the internet for locating information concerning supplier evaluation (Unpublished doctoral thesis). Bar-Ilan University, Ramat Gan, Israel. 


\section{APPENDIX - QUESTIONNAIRE}

1. Gender: 1. Male 2. Female

2. Age:

3. Mother tongue:

1. Hebrew

2. English

3. Russian

4. Other:

4. Years of education:

5. Education: 1. High school 2. Professional certificate 3. B.A. 4. M.A. and above 5. Other

6. Job sector: 1. Private 2. Public 3. Government

7. (Main) procurement area in which you deal:
1. Local
2. Overseas
3. Local \& overseas equally

8. Seniority as procurement manager (in years):

9. Size of (yearly) procurement in the organization
1. Less than 500,000 ILS
2. $0.5-1$ million ILS
3. 1 - 5 million ILS

4. 5 - 10 million ILS

5. Over 10 million ILS

10-11. What is your level of proficiency in the following tools: ( $1=$ none, $5=$ very high)

\begin{tabular}{|l|l|l|l|l|l|}
\hline & 1 & 2 & 3 & 4 & 5 \\
\hline 10. Office Tools & & & & & \\
\hline 11. Recent Technologies (e.g., tablets and smartphones) & & & & & \\
\hline
\end{tabular}

12. Have you ever searched the internet for information on suppliers in the following areas?

\begin{tabular}{|l|l|}
\hline Query subject & Yes \\
\hline Steadfastness \& financial standing & \\
\hline Pricelists & \\
\hline Legal aspects & \\
\hline Products and commodities & \\
\hline Recommendations & \\
\hline Geographic location & \\
\hline Prestige \& industry standing & \\
\hline Technical ability & \\
\hline Production adaptiveness & \\
\hline Warranty \& claims policies & \\
\hline Other & \\
\hline
\end{tabular}

13. If you answered yes to any of the above, rank the level of use of the following ( $5=$ very high, 1 $=$ no use)

\begin{tabular}{|l|l|l|l|l|l|}
\hline & 1 & 2 & 3 & 4 & 5 \\
\hline Steadfastness \& financial standing & & & & & \\
\hline Pricelists & & & & & \\
\hline Legal aspects & & & & & \\
\hline Products and commodities & & & & & \\
\hline Recommendations & & & & & \\
\hline Geographic location & & & & & \\
\hline Prestige \& industry standing & & & & & \\
\hline Technical ability & & & & & \\
\hline Production adaptiveness & & & & & \\
\hline Warranty \& claims policies & & & & & \\
\hline Other & & & & & \\
\hline
\end{tabular}


14. Rank to what extent you make use of each of the following information channels in the procurement process $(5=$ very high, $1=$ no use $)$

\begin{tabular}{|l|l|l|l|l|l|}
\hline & 1 & 2 & 3 & 4 & 5 \\
\hline Professional unions & & & & & \\
\hline Yellow pages & & & & & \\
\hline Publications or professional periodicals & & & & & \\
\hline Online or centralized information pools & & & & & \\
\hline Catalogues & & & & & \\
\hline Professional agents \&researchers & & & & & \\
\hline Commercial instructors & & & & & \\
\hline Scan company reports & & & & & \\
\hline Government information & & & & & \\
\hline Internet & & & & & \\
\hline Data collection companies & & & & & \\
\hline Commercial exhibitions \& fairs & & & & & \\
\hline Supplier guides & & & & & \\
\hline Direct mailing & & & & & \\
\hline Sales managers or representatives \& agents & & & & & \\
\hline Media & & & & & \\
\hline Personal knowledge & & & & & \\
\hline Parallel purchasers or buyers & & & & & \\
\hline Visits to suppliers factories & & & & & \\
\hline Clients & & & & & \\
\hline Foreign commercial \& official publications & & & & & \\
\hline Foreign attachés & & & & \\
\hline Israeli attachés overseas & & & & \\
\hline Overseas delegations & & & & \\
\hline
\end{tabular}

15. To what extent do you believe that you can find answers on the internet to any question you have regarding suppliers? $(5=$ very high, $1=$ not at all)

\begin{tabular}{|l|l|l|l|l|}
\hline 1 & 2 & 3 & 4 & 5 \\
\hline & & & & \\
\hline
\end{tabular}

16. To what extent do you agree with the following statements? $(5=$ very high, $1=$ not at all $)$

\begin{tabular}{|c|c|c|c|c|c|}
\hline I search the net for information about suppliers because: & 1 & 2 & 3 & 4 & 5 \\
\hline 1. It is accessible & & & & & \\
\hline 2. It is inexpensive & & & & & \\
\hline 3. It saves me time & & & & & \\
\hline 4. All the information regarding supplier's performances can be found there & & & & & \\
\hline 5. I can stay anonymous & & & & & \\
\hline 6. I can learn from it the supplier's service features & & & & & \\
\hline 7. I can learn from it the supplier's price features & & & & & \\
\hline 8. I can learn from it the supplier's delivery arrangements & & & & & \\
\hline 9. I can learn from it the supplier's warranty policies & & & & & \\
\hline 10. It gives me an intuitive feeling about the supplier & & & & & \\
\hline 11. My organization is connected to many databases & & & & & \\
\hline $\begin{array}{l}\text { 12. There is much awareness in my organization regarding use of the inter- } \\
\text { net to find information about suppliers }\end{array}$ & & & & & \\
\hline 13. It allows me to stay updated about suppliers & & & & & \\
\hline 14. It spares me from the traditional methods of locating suppliers & & & & & \\
\hline
\end{tabular}


15. I am not satisfied with information obtained by traditional methods

16. It helps me decide which potential suppliers to consider

17. It helps me to decide which potential suppliers to reject

18. I can get help from others in forums and professional groups

19. The wide range of information on the internet

20. To stay updated in general

\begin{tabular}{|l|l|l|l|l|l|}
\hline & & & & & \\
\hline & & & & & \\
\hline & & & & & \\
\hline & & & & & \\
\hline & & & & & \\
\hline
\end{tabular}

17. According to which criteria do you assess suppliers? $(5=$ very much so, $1=$ not at all $)$

\begin{tabular}{|l|l|l|l|l|l|}
\hline & 1 & 2 & 3 & 4 & 5 \\
\hline Quality & & & & & \\
\hline Delivery & & & & & \\
\hline Performance history & & & & & \\
\hline Warranty \& claims policy & & & & & \\
\hline Manufacturing services \& capacity & & & & & \\
\hline Price & & & & & \\
\hline Technical ability & & & & & \\
\hline Financial position & & & & & \\
\hline Manufacturing compatibility & & & & & \\
\hline Communication system & & & & & \\
\hline Reputation \& classification in the industry & & & & & \\
\hline The desire for business & & & & & \\
\hline Management \&organization & & & & \\
\hline Operational supervision & & & & & \\
\hline Repair services & & & & & \\
\hline Access & & & & & \\
\hline Impression & & & & & \\
\hline Packing ability & & & & & \\
\hline Work connections documentation & & & & & \\
\hline Geographic location & & & & & \\
\hline Amount of business in the past & & & & & \\
\hline Training assistance & & & & \\
\hline Mutual agreement & & & & \\
\hline
\end{tabular}

18. Which of the following criteria did you find on the internet? $(5=$ very much so, $1=$ not at all $)$

\begin{tabular}{|l|l|l|l|l|l|}
\hline & 1 & 2 & 3 & 4 & 5 \\
\hline Quality & & & & & \\
\hline Delivery & & & & & \\
\hline Performance history & & & & & \\
\hline Warranty \& claims policy & & & & & \\
\hline Manufacturing services \& capacity & & & & & \\
\hline Price & & & & & \\
\hline Technical ability & & & & & \\
\hline Financial position & & & & & \\
\hline Manufacturing compatibility & & & & & \\
\hline Communication system & & & & & \\
\hline Reputation \& classification in the industry & & & & & \\
\hline The desire for business & & & & & \\
\hline Management \&organization & & & & & \\
\hline Operational supervision & & & & & \\
\hline Repair services & & & & \\
\hline
\end{tabular}




\begin{tabular}{|l|l|l|l|l|l|}
\hline Access & & & & & \\
\hline Impression & & & & & \\
\hline Packing ability & & & & & \\
\hline Work connections documentation & & & & & \\
\hline Geographic location & & & & & \\
\hline Amount of business in the past & & & & & \\
\hline Training assistance & & & & & \\
\hline Mutual agreement & & & & & \\
\hline
\end{tabular}

19. What are your main activities on the internet (may check more than one answer)?

1. Email

2, Forums, support groups, distribution groups

3. Search and collection of information regarding general procurement issues, not related to suppliers

4. Search and collection of information regarding suppliers

5. Social networks (Facebook, Tweeter, Linkedin, Instagram...)

6. Other

20. How often do you use the internet for the following purposes?

\begin{tabular}{|c|c|c|c|c|c|c|}
\hline & 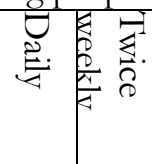 & $\begin{array}{l}\frac{\pi}{8} \\
\frac{8}{2} \\
\frac{\pi}{4}\end{array}$ & 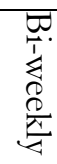 & 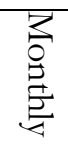 & $\begin{array}{l}\text { त्र } \\
\stackrel{0}{0} \\
\frac{0}{4}\end{array}$ & $\begin{array}{l}7 \\
9 \\
3 \\
9 \\
9\end{array}$ \\
\hline For continuous updates regarding procurement & & & & & & \\
\hline $\begin{array}{l}\text { For locating information regarding conferences } \\
\text { and professional gatherings }\end{array}$ & & & & & & \\
\hline For locating information about suppliers & & & & & & \\
\hline
\end{tabular}

21. How difficult is it for you to find information on the internet regarding suppliers? $(5=$ very much so, $1=$ not at all)

\begin{tabular}{|l|l|l|l|l|}
\hline 1 & 2 & 3 & 4 & 5 \\
\hline & & & & \\
\hline
\end{tabular}

22. What language do you use to search the internet for information on suppliers (may check more than one answer)?

English Hebrew Russian Arabic French Spanish

Other:

23. Rank the use of the preferred language $(5=$ very much so, $1=$ not at all $)$

\begin{tabular}{|l|l|l|l|l|l|}
\hline & 1 & 2 & 3 & 4 & 5 \\
\hline English & & & & & \\
\hline Hebrew & & & & & \\
\hline Russian & & & & & \\
\hline Arabic & & & & & \\
\hline French & & & & & \\
\hline Spanish & & & & & \\
\hline Other & & & & & \\
\hline
\end{tabular}


24. In order to find information regarding suppliers I... (5 =Highly agree, $1=$ Disagree $)$

\begin{tabular}{|l|l|l|l|l|l|}
\hline & 1 & 2 & 3 & 4 & 5 \\
\hline Search using search engines & & & & & \\
\hline Connect to links in sites I visit & & & & & \\
\hline Inquire in forums \& discussion groups & & & & & \\
\hline Visit sites recommended by my direct colleagues & & & & & \\
\hline Visit sites recommended by colleagues from other organizations & & & & & \\
\hline
\end{tabular}

25. What sites do you use to find supplier information? ( $5=$ very much, $1=$ not at all $)$

\begin{tabular}{|l|l|l|l|l|l|}
\hline & 1 & 2 & 3 & 4 & 5 \\
\hline Supplier's homepage & & & & & \\
\hline Databases such as: Lexis, Lplma, LexisNexis & & & & & \\
\hline Business information services, such as: BDI, D\&B & & & & & \\
\hline
\end{tabular}

26. To what degree do you enjoy the internet searching process? (5=very much, $1=$ not at all)

\begin{tabular}{|l|l|l|l|l|}
\hline 1 & 2 & 3 & 4 & 5 \\
\hline & & & & \\
\hline
\end{tabular}

27. My ability to find supplier information on the internet is: $(5=$ very high, $1=$ none $)$

\begin{tabular}{|l|l|l|l|l|}
\hline 1 & 2 & 3 & 4 & 5 \\
\hline & & & & \\
\hline
\end{tabular}

28. Rank the importance of the following criteria when examining the quality of the information found on the internet. $(5=$ very high, $1=$ none $)$

\begin{tabular}{|l|l|l|l|l|l|}
\hline & 1 & 2 & 3 & 4 & 5 \\
\hline Site writers & & & & & \\
\hline Site owners & & & & & \\
\hline Site purpose & & & & & \\
\hline Site address ending EDU/PRC & & & & & \\
\hline Last site update & & & & & \\
\hline Site design & & & & & \\
\hline Site's navigational ability & & & & & \\
\hline Links to other information sources & & & & & \\
\hline Privacy policy \& information security & & & & \\
\hline
\end{tabular}

29. How credible is the supplier information on the internet? $(5=$ very high, $1=$ none)

\begin{tabular}{|l|l|l|l|l|}
\hline 1 & 2 & 3 & 4 & 5 \\
\hline & & & & \\
\hline
\end{tabular}

30. To what degree do you agree with the following statement: 'In general, I am satisfied with the supplier information found on the internet'? ( $5=$ Highly agree, $1=$ Disagree)

\begin{tabular}{|l|l|l|l|l|}
\hline 1 & 2 & 3 & 4 & 5 \\
\hline & & & & \\
\hline
\end{tabular}


31. Indicate the amount of information you usually get regarding suppliers from the following sources: $(5=$ very much, $1=$ none $)$

\begin{tabular}{|c|c|c|c|c|c|c|}
\hline & Sources & 1 & 2 & 3 & 4 & 5 \\
\hline \multirow{9}{*}{$\begin{array}{l}\text { Official } \\
\text { sources }\end{array}$} & Professional unions & & & & & \\
\hline & Yellow pages & & & & & \\
\hline & Professional periodicals/publications & & & & & \\
\hline & Online/centralized databases & & & & & \\
\hline & Catalogues & & & & & \\
\hline & Agents \& Professional researchers & & & & & \\
\hline & Trade instructors & & & & & \\
\hline & Company reports & & & & & \\
\hline & Government info & & & & & \\
\hline \multirow{10}{*}{$\begin{array}{l}\text { Incidental } \\
\text { sources }\end{array}$} & Internet & & & & & \\
\hline & Data mining companies & & & & & \\
\hline & Trade exhibitions \& fairs & & & & & \\
\hline & Supplier instructors & & & & & \\
\hline & Direct mailing & & & & & \\
\hline & Representatives/agents \& sales managers & & & & & \\
\hline & Media & & & & & \\
\hline & Personal knowledge & & & & & \\
\hline & Other procurement officers & & & & & \\
\hline & Visits to supplier factory & & & & & \\
\hline \multirow{5}{*}{$\begin{array}{l}\text { Foreign } \\
\text { sources }\end{array}$} & Trade \& official publications & & & & & \\
\hline & Foreign attachés & & & & & \\
\hline & Israeli attaché' abroad & & & & & \\
\hline & Overseas delegations & & & & & \\
\hline & clients & & & & & \\
\hline
\end{tabular}

32. Do you agree with the following statements? $(5=$ Highly agree, $1=$ Disagree $)$

\begin{tabular}{|l|l|l|l|l|l|}
\hline Supplier info on the net... & 1 & 2 & 3 & 4 & 5 \\
\hline Saves me expenses for the information & & & & & \\
\hline Improves relations with supplier & & & & & \\
\hline Allows me to stay updated & & & & & \\
\hline Affects my decisions about managing the supplier & & & & & \\
\hline Affects my decisions regarding the organization's situation & & & & & \\
\hline Helps me better understand the supplier & & & & & \\
\hline $\begin{array}{l}\text { Leads me to ask the supplier questions that I wouldn't have } \\
\text { otherwise asked }\end{array}$ & & & & & \\
\hline Allows me to receive other evaluations from other sources & & & & & \\
\hline
\end{tabular}

33. How much the information you found on the internet affected your decisions regarding the evaluation of suppliers? ( 5 =Highly agree, $1=$ Disagree)

\begin{tabular}{|l|l|l|l|l|}
\hline 1 & 2 & 3 & 4 & 5 \\
\hline & & & & \\
\hline
\end{tabular}

34. Did you derive any other benefits, regarding the suppliers, from the information on the internet? 


\section{BIOGRAPHY}

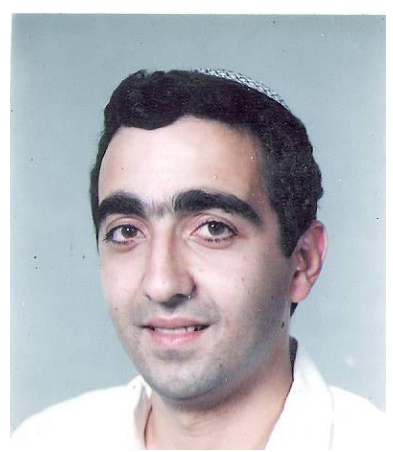

Dr. Dan Bouhnik is a faculty member in the Information Science department in Bar Ilan University (BIU) and in the Computer Science department in the Jerusalem College of Technology (JCT) in Israel. He is the author of a number of books used for teaching Advanced Computer Sciences and his professional interests include virtual learning and its effect on the thinking process, information needs of special groups as well as the infusion of new technologies in the learning environment.

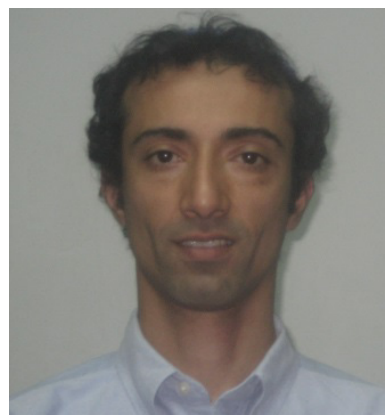

Dr. Yahel Giat is a tenured faculty member in the Department of Industrial Engineering and Management in the Jerusalem College of Technology. He holds a Ph.D. and an MSc. in Industrial Engineering from the Georgia Institute of Technology, an MSc. in Economics, a B.Sc. in Electrical Engineering and B.A. in Computer Sciences from the Israel Institute of Technology.

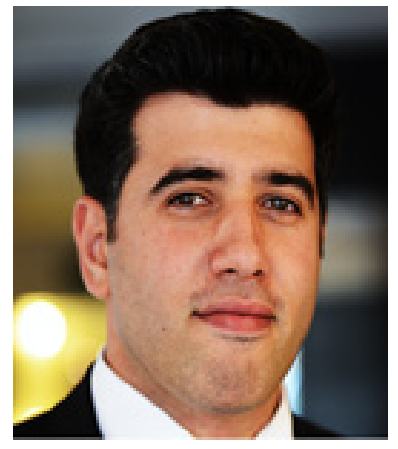

Mr. Issachar Zarruk is a Purchasing Manager at Bar-Ilan University (BIU) in Israel. He is pursuing a PhD in Information Sciences at BIU. He holds a Master degree in Logistics Management from BIU and a BA in Economics and Business Management from Ariel University. 